\title{
FORMULASI DAN UJI EFEKTIVITAS KRIM ANTIBAKTERI EKSTRAK DAUN NANGKA (Artocarpus heterophyllus Lam.) TERHADAP BAKTERI Staphylococcus aureus.
}

\author{
Nurul Syafriani Majid"1), Paulina. V. Y. Yamlean ${ }^{1)}$, Gayatri Citraningtyas ${ }^{1)}$ \\ ${ }^{1)}$ Program Studi Farmasi FMIPA UNSRAT Manado, 95115
}

\begin{abstract}
Jackfruit leaves contain saponins, flavonoids and tannins. Which are know to have antibacterial compounds. The purpose of this study is to make cream of jackfruit leaf extract with a concentration of 5\%, $10 \%$ and $15 \%$ and test the quality of preparations of jackfruit leaf extract cream and there is antibacterial effectiveness against Staphylococcus aureus bacteria. The method used is the ethanol extract of Jackfruit leaves by formulating it as an M/A type cream. The results showed the cream of jackfruit leaf extract fulfilled all the physical stability tests of the cream and in the antibacterial testing of cream of Jackfruit leaf extract could inhibit the effectiveness of Staphylococcus aureus bacteria. As concluded, the Jackfruit leaf extract Conclusions obtained by jackfruit leaf extract can be formulated as a cream with a concentration of $5 \%, 10 \%$ and $15 \%$, and cream preparations meet the cream quality test parameters, for testing the effectiveness of antibacterial to the biggest inhibition zone Staphylococcus aureus is $10.5 \mathrm{~mm}$ at $15 \%$ concentration.
\end{abstract}

Keywords: Jackfruit leaves, cream antibacterial, Staphylococcus aureus.

\begin{abstract}
ABSTRAK
Daun Nangka memiliki kandungan saponin, flavonoid dan tannin yang berperan sebagai senyawa antibakteri. Tujuan penelitian ini yaitu membuat krim ekstrak daun Nangka dengan konsentrasi 5\%, 10\% dan $15 \%$, menguji mutu dan efektivitas antibakteri krim ekstrak daun Nangka terhadap bakteri Staphylococcus aureus. Metode yang digunakan yaitu ekstrak etanol daun Nangka dengan memformulasikan sebagai krim dengan tipe M/A. Hasil penelitian menunjukkan krim ekstrak daun Nangka memenuhi semua uji kestabilan fisik krim dan dalam pengujian antibakteri krim ekstrak daun Nangka dapat menghambat efektivitas bakteri Staphylococcus aureus. Kesimpulan yang diapat ekstrak daun Nangka dapat diformulasikan sebagai krim dengan konsentrasi 5\%, $10 \%$ dan 15\%, dan sediaan krim memenuhi parameter uji kualitas krim, untuk pengujian efektivitas antibakteri terhadap Staphylococcus aureus zona hambat terbesar yaitu 10,5 mm pada konsentrasi $15 \%$.
\end{abstract}

Kata kunci: Daun Nangka, krim antibakteri, Staphylococcus aureus. 


\section{PENDAHULUAN}

Indonesia merupakan negara yang terletak di daerah khatulistiwa, yang memiliki suhu kamar berkisar $25-30^{\circ} \mathrm{C}$ ini merupakan negara yang berpotensi menjadi tempat yang subur untuk pertumbuhan bakteri dan jamur. Sebagian besar mikroorganisme ini bersifat patogen pada manusia, yang menyebabkan manusia sebagai inang mengalami infeksi dari mulai keadaan akut sampai kronis, salah satunya merupakan penyakit yang di sebabkan oleh infeksi bakteri Staphylococcus aureus (Tina dan Soraya, 2009).

Daun Nangka terdapat kandungan saponin, flavonoid dan tanin, pada buah nangka yang masih muda dan akarnya mengandung saponin (Hutapea, 1993). Daun Nangka dalam pengobatan tradisional digunakan sebagai obat demam, bisul, luka dan penyakit kulit (Prakash dkk, 2009). Senyawa saponin, flavonoid dan tannin dapat bekerja sebagai antimikroba dan merangsang pertumbuhan sel baru pada luka. . Penelitian sebelumnya (Wiguna, 2016) didapatkan hasil daun Nangka terdapat kandungan flavonoid, saponin dan tanin. Flavonoid dan saponin merupakan suatu senyawa yang mempunyai aktivitas antibakteri yang cara kerjanya merusak membran sitoplasma dan mendenaturasi protein sel bakteri dan merusak membran sel tanpa dapat diperbaiki lagi .

Berdasarkan latar belakang diatas dan berdasarkan hasil dari penelitian sebelumnya, peneliti tertarik untuk melakukan penelitian tentang pembuatan sediaan krim. Krim dipilih karena merupakan salah satu bentuk sediaan topikal umumnya yang digunakan untuk terapi yang bersifat lokal (Nugroho dan Akhmad, 2013). Bentuk sediaan krim lebih disukai oleh masyarakat karena mudah dibersihkan dan mudah menyebar (Ansel, 1989).

\section{METODE PENELITIAN Waktu dan Tempat Penelitian}

Penelitian ini dilaksanakan pada bulan Oktober 2018 sampai bulan Maret 2019 di Laboratorium Farmasi Lanjut Program Studi Farmasi Universitas Sam Ratulangi.

\section{Bentuk Penelitian}

Penelitian ini merupakan penelitian dengan menggunakan metode eksperimental laboratorium.

\section{Alat dan Bahan}

a. Alat

Peralatan yang digunakan dalam penelitian ini ialah pisau, oven (Infois HT), timbangan analitik (AE Adam), blender, gelas kimia (Pirex), batang pengaduk, gelas ukur, corong ,gelass kimia (Pirex), kamera, label, hot plate (Nesco Lab), inkubator (Ecocell), cawan petri, pH meter (Elmectron), autoklaf (ALP), erlenmeyer (Pirex), tabung reaksi (Iwaki asahi glass), mistar, wadah krim (Tube), Ayakan mesh 200 (Eckhardt), lumping dan alu, Laminar Air Flow (LAF), pipet mikro (eccopipette ${ }^{\mathrm{TM}}$ ), pot krim, sudip, mistar, jangka sorong, pencadang, jarum ose, pingset.

b. Bahan

Bahan yang digunakan dalam penelitian ini ialah ekstrak daun Nangka, etanol 96\%, Nutrien Agar (NA), asam stearat, gliserin, metil paraben, propil paraben, paraffin cair, setil alcohol 96\%, adeps lanae, aquades, bakteri Staphylococccus aureus, alumunium foil. 


\section{Prosedur Penelitian}

\section{Ekstraksi}

Ekstraksi sampel daun Nangka menggunakan metode maserasi. Sebanyak $400 \mathrm{~g}$ dimasukkan dalam bejana, ditambahkan pelarut etanol $96 \%$ sebanyak 2 liter, didiamkan selama 3 hari sambil sesekali diaduk, setelah 3 hari ekstrak disaring dengan menggunakan kertas saring dan menghasilkan filtrat dan residu. Residu yang ada kemudian direndam lagi (remaserasi) dengan pelarut yang sama selama 2 hari sambil sesekali diaduk. Setelah 2 hari, sampel disaring sehingga menghasilkan filtrat dan residu. Filtrat 1 dan filtrat 2 dicampurkan menjadi satu lalu dievaporasi menggunakan rotary evaporator, lalu diuapkan menggunakan waterbath sehingga diperoleh ekstrak kental. Ekstrak kental yang dihasilkan dibiarkan pada suhu ruangan hingga seluruh pelarut etanol menguap. Ekstrak kental yang telah dihasilkan ditimbang dan disimpan dalam wadah gelas tertutup sebelum digunakan untuk pengujian.

\section{Formulasi dan Pembuatan Krim Ekstrak daun Nangka}

Pada penelitian ini dibuat sediaan krim ekstrak daun Nangka dengan tiga variasi konsentrasi, yaitu 5\%,10\% dan $15 \%$ dapat dilihat pada Tabel 1.
Basis krim tipe M/A yang dibuat terdiri dari dua fase yaitu fase minyak (parafin cair, adeps lanae, asam stearat, nipasol) dan fase air (TEA, nipangin). Fase - fase tersebut dipanaskan pada suhu $70^{\circ} \mathrm{C}$ ditangas air. Fase minyak dipindahkan kedalam lumpang dan yang telah berisi fase air, kemudian diaduk sampai homogen hingga terbentuk massa krim.

Pembutan krim ekstrak daun Nangka dengan cara mencampurkan basis krim dengan ekstrak daun nangka sesuai dengan konsentrasi. Formulasi krim ekstrak Daun Nangka dengan konsentrasi 5\%, 10\%, 15\%.

\section{Pengujian Sediaan Krim}

a. Organoleptis

Pemeriksaan organoleptis meliputi bentuk, warna danbau yang diamati secara visual (Erawati dan Zaky, 2016). Spesifikasi krim yang harus dipenuhi adalah memiliki konsistensi lembut, warna sediaan homogen, dan harum.

b. Uji daya lekat

Pengujian daya lekat sediaan dilakukan dengan cara krim diletakkan pada satu sisi kaca objek dengan sisi bawahnya telah dipasangkan tali untuk mengikat beban. Kemudian ditempelkan pada kaca objek yang lain. Beban yang digunakan adalah $80 \mathrm{~g}$. Kemudian diamati waktu yang dibutuhkan beban tersebut untuk memisahkan kedua kaca

\begin{tabular}{cccc}
\hline Komponen & Konsentrasi & Konsentrasi & Konsentrasi \\
& $5 \%$ & $10 \%$ & $15 \%$ \\
\hline Ekstrak daun Beluntas & $2,5 \mathrm{~g}$ & $5 \mathrm{~g}$ & $7,5 \mathrm{~g}$ \\
Asam stearate & $7,25 \mathrm{~g}$ & $7,25 \mathrm{~g}$ & $7,25 \mathrm{~g}$ \\
TEA & $0,75 \mathrm{~g}$ & $0,75 \mathrm{~g}$ & $0,75 \mathrm{~g}$ \\
Adeps lanae & $1,5 \mathrm{~g}$ & $1,5 \mathrm{~g}$ & $1,5 \mathrm{~g}$ \\
Parrafin Cair & $12,5 \mathrm{~g}$ & $12,5 \mathrm{~g}$ & $12,5 \mathrm{~g}$ \\
Nipagin & $0,05 \mathrm{~g}$ & $0,05 \mathrm{~g}$ & $0,05 \mathrm{~g}$ \\
Nipasol & $0,025 \mathrm{~g}$ & $0,025 \mathrm{~g}$ & $0,025 \mathrm{~g}$
\end{tabular}


$\begin{array}{lrrr}\text { Aquades ad } & 50 & 50 & 50\end{array}$

a. $\mathrm{Uji} \mathrm{pH}$

Tabel 1.Formulasi Krim Ekstrak Etanol Daun Beluntas 5\%,10\%,15\%

Krim pada masing-masing tipe dan konsentrasi disiapkan, kemudian diukur pHnya menggunakan $\mathrm{pH}$ meter dan selanjutnya dilihat perubahan warna yang terjadi. Dicatat nilai $\mathrm{pH}$ masing-masing formula. Nilai $\mathrm{pH}$ yang ideal yaitu 4,5-6,5 (Budiman, 2008)

b. Uji daya sebar

Ditimbang 1 gram krim, diletakkan ditengah cawan petri yang berada pada posisi terbalik. Diletakkan sekeping kaca objek transparan yang lain diatas krim, dibiarkan 1 menit. Kemudian ditambahkan beban 200 gram beban tambahan, didiamkan 1 menit. Dicatat diameter krim yang menyebar (Indrayuda et al, 2010). Daya sebar yang baik yaitu 5,6-6,4 (Rajalahksmi, 2009).

c. Uji Homogenitas

Uji homogenitas dilakukan dengan meletakkan krim secukupnya diantara dua kaca objek, kemudian diamati adanya butiran kasar atau tidak (Setiawati dkk.,2014).

d. Uji Tipe Emulsi

Pengujian tipe emulsi menggunakan metode pengenceran. Krim yang telah dibuat dimasukkan kedalam gelas kimia kemudian diencerkan dengan aquadest, jika emulsi tidak tercampur dengan air maka tipe emulsinya $\mathrm{A} / \mathrm{M}$, jika tercampur dengan air maka tipe emulsinya $\mathrm{M} / \mathrm{A}$.

\section{e. Cycling Test}

Sampel krim disimpan pada suhu $4^{\circ} \mathrm{C}$ selama 24 jam lalu dipindahkan ke dalam oven bersuhu $40^{\circ} \pm 2^{\circ} \mathrm{C}$ selama 24 jam (satu siklus). Uji dilakukan sebanyak 6 siklus,kemudian diamati perubahan fisik yang terjadi (apakah ada pemisahan). Penyimpanan sampel krim pada suhu tinggi $40^{\circ}$ (Rieger M, 2000).

\section{Pengujian Aktivitas Antibakteri}

Alat-alat gelas yang digunakan dalam penelitian ini disterilkan terlebih dahulu dengan menggunakan autoklaf pada suhu 121 ${ }^{\circ} \mathrm{C}$ selama 15 menit. Pinset, jarum ose dan $\mathrm{L}$ glass dipijarkan diatas api bunsen (Ortez, 2005).

Uji aktivitas antibakteri terhadap krim ekstrak daun Nangka menggunakan bakteri Staphylococcus aureu dengan cara difusi agar. 3 sumuran untuk setiap konsentrasi krim ekstrak Etanol daun Nangka 5\%, 10\% dan $15 \%$ dan dua sumuran lain untuk kontrol positif (krim Gentamicin) dan kontrol negatif (basis krim).

Pengamatan dilakukan setelah 1 x 24 jam masa inkubasi. Daerah bening pada sekitaran cakram menunjukan kepekaan bakteri terhadap antibiotik atau aktivitas antibakteri dari bahan uji yang digunakan dapat ditentukan berdasarkan diameter zona bening. Diameter zona bening diukur dalam satuan milimeter $(\mathrm{mm})$ menggunkan jangka sorong dengan cara diukur diameter zona bening horizontal ditambahkan dengan diameter zona bening vertikal lalu dibagi dua dan dikurangi besar sumuran $7 \mathrm{~mm}$. Kemudian hasil pengukuran zona bening, dibandingkan berdasarkan teori menurut Davis dan Stout (1971). 


\section{HASIL DAN PEMBAHASAN}

Tabel 2. Hasil Uji Organoleptik Krim Ekstrak Etanol Daun Nangka

\begin{tabular}{|c|c|c|c|c|c|c|}
\hline \multicolumn{4}{|c|}{ Sebelum Penyimpanan } & \multicolumn{3}{|c|}{ Setelah Penyimpanan } \\
\hline Krim & Bau & Warna & Bentuk & Bau & Warna & Bentuk \\
\hline Basis & $\begin{array}{l}\text { Khas } \\
\text { Minyak } \\
\text { Hewani }\end{array}$ & Putih & Semi Padat & $\begin{array}{l}\text { Khas } \\
\text { Minyak } \\
\text { Hewani }\end{array}$ & Putih & Semi Padat \\
\hline K5\% & $\begin{array}{l}\text { Khas } \\
\text { Ekstrak }\end{array}$ & $\begin{array}{l}\text { Hijau } \\
\text { Muda }\end{array}$ & Semi padat & $\begin{array}{l}\text { Khas } \\
\text { Ekstrak }\end{array}$ & Hijau & Semi padat \\
\hline $\mathrm{K} 10 \%$ & $\begin{array}{l}\text { Khas } \\
\text { Ekstrak }\end{array}$ & Hijau & Semi padat & $\begin{array}{l}\text { Khas } \\
\text { Ekstrak }\end{array}$ & Hijau Tua & Semi padat \\
\hline $\mathrm{K} 15 \%$ & $\begin{array}{l}\text { Khas } \\
\text { Ekstrak }\end{array}$ & $\begin{array}{l}\text { Hijau } \\
\text { Tua }\end{array}$ & Semi padat & $\begin{array}{l}\text { Khas } \\
\text { Ekstrak }\end{array}$ & Hijau Tua & Semi padat \\
\hline
\end{tabular}

Tabel 3. Hasil Uji Homogenitas Krim Ekstrak Daun Nangka

\begin{tabular}{lcc}
\hline & Sebelum Penyimpanan & Setelah Penyimpanan \\
\hline Krim & Homogenitas & Homognenitas \\
\hline Basis & Homogen & Homogen \\
K5\% & Homogen & Homogen \\
K10\% & Homogen & Homogen \\
K15\% & Homogen & Homogen \\
& & \\
\hline
\end{tabular}

Tabel 4. Hasil Uji pH Krim Ekstrak Etanol Daun Nangka

\begin{tabular}{lcc}
\hline \multicolumn{2}{c}{ Sebelum Penyimpanan } & Setelah Penyimpanan \\
\hline Krim & $\mathbf{p H}$ & $\mathbf{p H}$ \\
\hline Basis & 6,09 & 6,05 \\
K5\% & 6,01 & 5,17 \\
K10\% & 5,09 & 6,00 \\
K15\% & 5,07 & 6,01 \\
\hline
\end{tabular}

Tabel 5. Hasil Uji Daya Sebar Krim Ekstrak Etanol Daun Nangka

\begin{tabular}{lcl}
\hline & Sebelum Penyimpanan & \multicolumn{1}{c}{ Setelah Penyimpanan } \\
\hline Krim & Diameter Sebar Krim & Diameter Sebar Krim \\
\hline
\end{tabular}




\begin{tabular}{lll}
\hline Basis & $6,5 \mathrm{~cm}$ & $6,0 \mathrm{~cm}$ \\
$\mathrm{~K} 5 \%$ & $5,6 \mathrm{~cm}$ & $5,4 \mathrm{~cm}$ \\
$\mathrm{~K} 10 \%$ & $5,6 \mathrm{~cm}$ & $5,2 \mathrm{~cm}$ \\
$\mathrm{~K} 15 \%$ & $5,3 \mathrm{~cm}$ & $5,0 \mathrm{~cm}$ \\
\hline
\end{tabular}

Tabel 6. Hasil Uji Daya Lekat Krim Ekstrak Etanol Daun Nangka

\begin{tabular}{lcc}
\hline & Sebelum Penyimpanan & Setelah Penyimpanan \\
\hline Krim & Waktu & Waktu \\
\hline Basis & 6,8 detik & 5,0 detik \\
K5\% & 5,0 detik & 3,0 detik \\
K10\% & 3,2 detik & 1,9 detik \\
K15\% & 2,5 detik & 1,7 detik \\
\hline
\end{tabular}

Tabel 7. Pengujian Tipe Emulsi Krim Ekstrak Etanol Daun Nangka

\begin{tabular}{lcl}
\hline & Sebelum Penyimpanan & Setelah Penyimpanan \\
\hline Krim & Tipe Emulsi & Tipe Emulsi \\
\hline Basis & Minyak dalam Air & Minyak dalam Air \\
K5\% & Minyak dalam Air & Minyak dalam Air \\
K10\% & Minyak dalam Air & Minyak dalam Air \\
K15\% & Minyak dalam Air & Minyak dalam Air \\
\hline
\end{tabular}

Tabel 8. Hasil Pegujian Mikrobiologi Krim Ekstrak Etanol Daun Nangka

\begin{tabular}{lcccc}
\hline Formulasi & \multicolumn{4}{c}{ Diameter daerah hambatan (mm) } \\
& Ulangan I & Ulangan & Ulangan & Rata-rata \\
& I & II & III & \\
\hline K (-) & 0 & 0 & 0 & 0 \\
K (+) & 11,5 & 11,5 & 11,5 & 11,5 \\
K5\% & 9 & 8 & 6,5 & 7,8 \\
K10\% & 9,5 & 10 & 9 & 9,5 \\
K15\% & 11,5 & 11 & 9 & 10,5 \\
\hline
\end{tabular}

\section{PEMBAHASAN}

Pengujian fisik terhadap sediaan krim ekstrak daun Nangka agar diketahui kelayakan dan kestabilan krim. Pengujian organoleptik meliputi bentuk, warna dan bau. Krim yang dihasilkan memiliki bentuk setengah padat yang merupakan karakteristik dari krim pada umumnya, setelah dilakukan penyimpanan terjadi perubahan warna pada sediaan krim dari warna hijau terang menjadi hijau gelap ini dapat diartikan bahwa krim ekstrak daun Nangka memiliki stabilitas yang tidak baik dalam penyimpanan. Setelah dilakukan penyimpanan krim selama 6 siklus 
hasil pengamatan yang dilakukan tidak terjadi pemisahan fase, hal ini menunjukkan sediaan krim bersifat stabil. Hal ini disebabkan setelah sediaan krim didinginkan akan terjadi pelepasan air pada sediaan krim, namun film pengemulsi ketiga sediaan konsentrasi krim dapat bekerja kembali dibawah tekanan yang diinduksi oleh es sehingga tidak terjadi pemisahan fase dan sistem emulsi dikatakan stabil.

Homogenitas merupakan faktor yang penting karena dapat berpengaruh terhadap distribusi obat. Sediaan dikatakan homogen bila terdapat persamaan warna dan tidak adanya partikel atau bahan kasar yang dapat diraba (Syamsuni, 2005). Hasil pengamatan secara visual sebelum penyimpanan krim menunjukkan susunan krim yang homogen, karena sudah tidak ada gumpalan dan butiran kasar yang terdapat didalam krim, begitupun halnya setelah penyimpanan krim pada pengamatan secara visual menunjukkan susunan krim yang homogen. Hal ini sesuai dengan persyaratan homogenitas krim yaitu krim harus menunjukkan susunan yang homogen serta tidak adanya butiran kasar pada krim (Depkes RI, 1985).

Uji daya lekat sediaan krim ekstrak daun Nangka dilakukan untuk menunjukkan kemampuan krim melekat dan melapisi permukaan kulit sewaktu digunakan agar dapat bekerja secara maksimal. Semakin lama krim melekat pada kulit maka semakin baik krim yang dihasilkan karena zat aktif yang terkandung dalam krim semakin lama melekat pada kulit dan memberikan efek. Hasil pengukuran daya lekat krim ektrak daun Nangka yang memiliki daya lekat paling lama yaitu krim dengan konsentrasi 5\% dengan waktu 5,6 detik. Hasil uji ini menunjukkan adanya penambahan ekstrak menyebabkan daya lekat semakin singkat.

Uji $\mathrm{pH}$ pada krim untuk mengetahui kadar asam dan basa dari sediaan krim. Nilai
$\mathrm{pH}$ untuk sediaan topikal harus sesuai dengan $\mathrm{pH}$ kulit yaitu 4,5-6,5. Pengujian $\mathrm{pH}$ pada sediaan krim menggunakan $\mathrm{pH}$ meter dengan memasukkan alat $\mathrm{pH}$ meter kedalam krim yang telah dibuat .Hasil pengukuran $\mathrm{pH}$ krim sebelum penyimpanan dan sesudah penyimpan krim ini sesuai dengan $\mathrm{pH}$ kulit sehingga aman digunakan pada kulit.

Pengujian daya sebar merupakan pengujian yang dilakukan untuk mengetahui kemampuan penyebaran krim. Daya sebar 5-7 $\mathrm{cm}$ menunjukkan konsistensi yang sangat nyaman dalam penggunaan (Garg dkk, 2002). Dari hasil uji daya sebar dengan menggunakan beban yang sama terlihat sedikit perubahan, diketahui semakin tinggi konsentrasi penambahan ekstrak krim maka semakin rendah daya sebar krim, karena semakin kental konsistensinya, maka semakin kecil daya sebar yang dihasilkan.

Pengujian tipe emulsi menggunakan metode pengenceran dengan cara mengencerkan 1 g krim kedalam 100 mL aquadest dan diaduk hingga homogen, apabila krim tersebut larut dalam aquades maka tipe krim ini yaitu minyak dalam air (M/A). hal ini disebabkan karena jumlah fase terdispersi (minyak/lemak) yang digunakan dalam krim lebih kecil dari fase pendispersi (fase air), sehingga fase minyak akan terdispersi merata ke dalam fase air dan membentuk emulsi minyak dalam air dengan bantuan emulgator.

Pengujian aktivitas antibakteri ditentukan berdasarkan diameter zona hambat disekitar pencadangan/sumuran media Nutrien Agar (NA). hasil pengujian yang dilakukan, krim ekstrak daun Nangka dengan konsentrasi 5\%, 10\% dan 15\% menunjukan aktivitas antibakteri dengan adanya zona hambat disekitar sumuran. Diameter zona hambat disekitar sumuran diukur menggunakan jangka sorong dengan cara mengukur secara horizontal dan vertical kemudian hasul yang didapatkan dikurangi 
diameter sumuran $7 \mathrm{~mm}$. Dari hasil yang didapat krim ekstrak daun Nangka dengan konsentrasi 5\%, $10 \%$ dan $15 \%$ dapat menghabat aktivitas bakteri Staphylococcus aureus, dengan konsentrasi $15 \%$ memiliki zona hambat terbesar yaitu $10.5 \mathrm{~mm}$. Zona hambat yang terdepat disekitaran sumuran disebabkan oleh adanya kandungan zat aktiv dari ekstrak daun Nangka yang dapat memberika efek terhadap bakteri Staphylococcus aureus. Kandungan flavonoid yang terkandung dalam ekstrak daun Nangka mengandung gugus fenol, dimana fenol dapat menyebabkan denaturasi protein dan merusak membran sel bakteri (Samsumaharto dan Hartanto, 2010). Menyebabkana terjadinya kerusakan permeabilitas dinding sel bakteri, mikrosom, dan lisosom sebagai hasil intetraksi antara flavonoid dan DNA bakteri (Sabir, 2005).

Analisis data dapat dilakukan dengan menggunakan uji statistic one way ANOVA dengan tujuan sebagai dasar pengambilan keputusan dari suatu hipotesis. Hasil uji one way ANOVA pada penelitian ini yaitu menunjukkn adanya perbedaan antar perlakuan sig $(0,000)<(0,05)$ artinya $\mathrm{P}$-value $<\alpha(0,05)$, maka $\mathrm{H}_{0}$ ditolak $\mathrm{H}_{1}$ diterima. Maka terdapat perbedaan signifikan zona bening antara basis krim dan krim ekstrak daun Nangka konsentrasi 5\%, 10\% dan 15\%. Pengujian dilanjutkan dengan uji Duncan untuk melihat perlakuan mana yang memberikan efek berbeda atau tidak.

\section{KESIMPULAN}

Ekstrak etanol daun Nangka dapat diformulasikan sebagai sediaan krim dengan konsentrasi 5\%, 10\% dan 15\%, dan sudah memenuhi uji kestabilan fisik.Krim ekstrak etanol daun Nangka menunjukkan efektivitas antibakteri terhadap Staphylococcus aureus. Krim ekstrak etanol daun Nangka dengan zona hambat terbesar yaitu $10,5 \mathrm{~mm}$ pada konsentrasi $15 \%$.

\section{SARAN}

Perlu dilakukan penelitian lagi untuk pengujian ditambahkan uji lainnya seperti uji viskositas terhadap sediaan krim agar dapat memenuhi semua parameter uji kualitas.

\section{DAFTAR PUSTAKA}

Ansel, H.C., 1989. Pengantar Bentuk Sediaan Farmasi, diterjemahkan oleh Farida Ibrahim, Asmanizar, Iis Aisyah, Edisi keempat, 255-271, 607-608, 700. Jakarta : UI Press.

Budiman, M.H., 2008. Uji stabilitas Fisik Krim Antioksidan Ekstrak Serbuk Tomat [Skripsi]. FMIPA UI, Jakarta.

David, W.W, Sout, T.R. 1971. Disc Plate Methodes of Micribiological Antibiotics Assay. Microbiology Journal. 22(4):659-665.

Garg, A., Aggarwal, D., Garg, S., Sigla, A.K. 2002. Spreading of Semisolid Formulation: An Update. Pharmaceutical Technology. 84: 102

Hutapea, J.R. 1993. Inventaris Tanaman Obat Indonesia, edisi II. Jakarta: Depkes RI Badan Penelitian dan Pengembangan Kesehatan .

Nugroho., Akhmad K. 2013. Sediaan Transdermal: Solusi Masalah Terapi Obat. Yogyakarta :Pustaka Pelajar Yogyakarta.

Oretz, J. H. 2005. Disk Diffusion testing in manual of antimicrobial susceptibility testing. Marie B. coyle (Coord. Ed). American society for microbiologr. Amerika.

Prakash, Om., K, Rajesh., M , Anurag., G, Rajiv. 2009. Artocarpus heterophyllus (Jackfruit): An overview. India: Review Article. 3(6) 353-358 
Rajalakshmi, G. N. 2009. Formulation and Evaluation of Clotrimazole and Ichtammol Oitment. International Journal of Pharma and Bioscience 4:10-12

Rieger, M. 2000. 10. Harry's Cosmeticology (8 Edition). New York: Chemical

Publishing Co Inc

Sabir, A. 2005. Aktivitas Antibakteri Flavonoid Propolis Trigona sp Terhadap bakteri Streptococcus mutans (in vitro). Majalah Kedokteran Gigi. 38, (3), 135-140.

Setiawati, E., Nursal, F. K,. Elfiyani, R. 2014. Pengaruh Peningkatan Konsentrasi Setil Alkohol Sebagai Pengental
Terhadap Stabilitas Fisik Krim Tipe M/A Ekstrak Rimpang Jahe Gajah (Zingiber Officinale Roscoe). Jakarta: Fakultas FarmasiUniversitas Muhamadiyah.

Syamsuni, H. 2005. Farmasetika Dasar dan Hitungan Farmasi. Jakarta : Penerbit Buku Kedokteran EGC.

Tina R, Rani M., Soraya R.M. 2009. Penelusuran Senyawa Aktif Ekstrak Daun Sukun(Artocarpus altilis) Terhadap Staphylococcus aureus, Microsporum gypseum dan Candida albicans. Laporan Akhir Penelitian Hibah Bersaing Tahun Ke-1. Bandung: Departemen Pendidikan Nasional UnPad Fakultas Farmasi. 